\title{
Editorial: The Status of Marine Fisheries in East Asia
}

\author{
Daniel Pauly ${ }^{1 *}$, Cui Liang ${ }^{2,3,4}$ and Weiwei Xian ${ }^{2,3,4}$ \\ ${ }^{1}$ Sea Around Us, Institute for the Ocean and Fisheries, University of British Columbia, Vancouver, BC, Canada, ${ }^{2}$ CAS Key \\ Laboratory of Marine Ecology and Environmental Sciences, Institute of Oceanology, Chinese Academy of Sciences, Qingdao, \\ China, ${ }^{3}$ Laboratory for Marine Ecology and Environmental Science, Qingdao National Laboratory for Marine Science and \\ Technology, Qingdao, China, ${ }^{4}$ Center for Ocean Mega-Science, Chinese Academy of Sciences, Qingdao, China
}

Keywords: stock assessments, catch time-series, length frequency data, China, Korea, Japan

\section{Editorial on the Research Topic}

\section{The Status of Marine Fisheries in East Asia}

East Asia includes some of the countries with the highest domestic fisheries catch in the world, notably China and Japan. The status of their fisheries matters to the world because these countries also deploy huge fishing fleets into the high seas and the Exclusive Economic Zones of other countries, tasked with compensating for stagnating or even declining local fisheries resources.

Rebuilding East Asian fishery resources is a challenge, however, because their status is often unknown. This situation is due, at least in part, to the fact that time series of data suitable for analysis requiring sophisticated, but data-demanding methods, being scarce or not available in the region.

This dissatisfying state of affairs is now gradually being overcome, notably through the

OPEN ACCESS

Edited and reviewed by: Yngvar Olsen Norwegian University of Science and Technology, Norway

*Correspondence: Daniel Pauly

d.pauly@oceans.ubc.ca

Specialty section:

This article was submitted to Marine Fisheries, Aquaculture and

Living Resources,

a section of the journal

Frontiers in Marine Science

Received: 30 September 2021 Accepted: 26 October 2021 Published: 25 November 2021

Citation:

Pauly D, Liang C and Xian W (2021)

Editorial: The Status of Marine

Fisheries in East Asia.

Front. Mar. Sci. 8:787217.

doi: 10.3389/fmars.2021.787217 development, by Froese et al. $(2017,2018)$, of stock assessment methods that require less data, but still produce results that are reliable results enough to inform fisheries management.

These approaches consist of:

(1) the "CMSY/BSM" method (Froese et al., 2017), which relies essentially on time-series of catches-preferably spanning two decades or more-and ancillary data to estimate time series of abundance or "biomass" for the assessed populations or "stocks";

(2) the “LBB' method (Froese et al., 2018), which uses length-frequency samples, i.e., multiple measurements of fish lengths, to infer the status of a fish populations or stocks, and

(3) A reconceptualization of classical yield-per-recruit (Y/R) analysis (Beverton and Holt, 1957) such that can provide estimates of the ratio of current to unexploited biomass.

These methods were introduced to Chinese scientists via a highly successful training course held in Qingdao during June 16-20, 2019. The course was taught by the authors and Dr. M.L. Deng Palomares, with Dr. Rainer Froese participating remotely.

During the course, multiple stock assessments were run which eventually evolved into the bulk of the articles presented here. A few articles that were written previously and/or independently of the course are also included.

Altogether, 161 East Asian marine stocks were assessed, of which 132 pertained to finfishes and 29 to invertebrates, especially squids. Of these, 83 stocks were exploited along the coast of the Chinese Mainland (Liang, Xian, Pauly et al.; Liang, Xian, Liu et al.; Wang, Wang, Liu et al.; Wang X. et al.; Zhai and Pauly(a); Zhai et al.; Zhang L. et al.), 22 from around Taiwan (Ju, Chen et al.; Ju, Tian et al.; Liang Xian, Liu et al.), 50 around Japan (Liang, Xian, Liu et al.; Ren and Liu; Wang, Wang, Liang et al.; Wang, Liang et al.; Zhang S. et al.) and 6 around South Korea (Liang, Xian, Liu et al.). 
As is the case for all stock assessment methods, the CMSY/BSM and LBB methods rely on reliable input data, i.e., catch (and catch-per-unit-effort) time series for CMSY/BSM and length-frequency data for LBB. Problematic inputs, and unrealistic constraints ("priors") will lead to biased parameter estimates, and a few of the 161 estimates presented here will be biased up- or downward. However, there is no reason to assume a systematic bias.

Overall, these assessments jointly represent the most comprehensive evaluation of the Status of Marine Fisheries in East Asia, and they paint a very sobering picture. Thus, if one gives each stock a similar weight, one can compute from these assessments, for each region, the average biomass (or fish resource abundance) currently remaining as a percentage of its inferred biomass or abundance in the absence of fishing.

These mean percentages are 25\% for the Chinese Mainland, $16 \%$ for Taiwan, $30 \%$ for Japan and $26 \%$ for South Korea; all of these averages are well below 50\%, the level the classical stock assessment model of Schaefer $(1954,1957)$ requires for Maximum Sustainable Yield to be generated (Pauly and Froese, 2020). The regional means were derived from several ratio estimates that were higher, i.e., there are stocks in East Asia that are not overfished. However, there were far more stocks that had extremely low values of current to unfished biomass, with the result that the mean ratio for East Asia was 25\%.

That overfishing is prevalent in East Asia was previously known (Srinivasan et al., 2012; Li et al., 2017). However, most of these assessments include estimates of the parameters also required to compute the time needed for overfished stocks to recover, given a reduction of fishing pressure (see Demirel et al., 2020). Thus, this makes it possible for fisheries scientists in East Asia to straightforwardly compute fishing quotas allowing for increasing stock sizes by a factor of two in the average, but which would allow for the social cost of a reduction of fishing effort to be smaller than the benefits gained from abundant stocks embedded in functioning ecosystems.

Indeed, at least for the Chinese Mainland, Zhai and Pauly(b) found, based on the conversion of 19 food web models into particle-size distribution spectra, that the functioning of coastal marine ecosystem of East Asia are gradually eroded due to the fisheries-induced disappearance of large fish species and miniaturization of the remaining species.

Thus, rebuilding stocks in East Asia would not only benefit fisheries economically, in terms of their catches, but also reestablish the functioning, rich marine ecosystems that enable fisheries to flourish in the longer term.

\section{东亚地区渔业状况}

东亚包括一些世界上国内渔业捕捞量最高的国家,特别 是中国和日本。为弥补国内停滞甚至衰退的渔业资源, 东亚 国家会向公海和其他国家的专属经济区派出庞大的捕捞船 队,因此,它们的渔业状况备受世界关注。

重建东亚渔业资源颇具挑战, 因为其资源状态往往是未 知的。造成这种情况的部分原因在于, 复杂的资源评估方 法需要大量的时间序列数据, 而这种数据在东亚地区通常 很少见或不存在。
目前, 通过德国渔业学家Rainer Froese及其同事开发的几 种数据缺乏条件下的渔业种群评估方法, 这种状况正逐渐 被改善。这些方法需要较少的渔业数据作为输入, 但仍能 产生较为可靠的结果来为渔业管理提供参考。 这些方法包括:

(1) “CMSY/BSM”方法(Froese et al., 2017), 它主要依赖于渔获 量的时间序列 (时间跨度最好超过二十年) 以及辅助数 据来估计被评估种群或群体的丰度或生物量。

(2) “LBB”方法(Froese et al., 2018), 该方法使用测量得到的体 长频率数据,来推断渔业种群或群体的状态。

(3) 对经典的单位补充量渔获量分析(Beverton and Holt, 1957) 进行概念重建, 以估计当前生物量与未开发生物量 的比值。

这些方法通过2019 年 6 月 18-20 日在青岛举办的培训课程被 介绍给来自多所高校和科研院所的中国渔业学者。该课程 主要由Maria Lourdes D. Palomares博士和Daniel Pauly博士教 授,Rainer Froese 博士远程参与。在培训课程期间,上述方法 被用于东亚地区众多渔业种群或群体的资源评估,并最终形 成了本集刊的大部分文章。集刊中另有部分文章独立于本 次培训课程,也在后期进行了增补。

本集刊共对161个东亚海洋种群进行了评估,包括132种鱼 类,29种无脊椎动物。在这些被评估的种群中, 有 83 个种群 主要在中国大陆沿海被开发(Liang, Xian, Pauly et al.; Liang, Xian, Liu et al.; Wang, Wang, Liu et al.; Zhai and Pauly (a); Zhai et al.; Zhang L. et al.),22个种群主要被台湾地区开发(Ju, Chen et al.; Ju, Xian et al.; Liang, Liu et al.), 分布于日本海域的种 群50个(Liang, Xian, Liu et al.; Ren and Liu; Wang, Wang, Liang et al.; Wang, Liang et al.; Zhang S. et al.), 韩国海域6个(Liang, Xian, Liu et al.)。

与所有种群评估方法的情况一样,CMSY/BSM 和LBB 方法 依赖于可靠的输入数据, 即CMSY/BSM的渔获量（和单位努 力量渔获量) 时间序列和LBB 的体长频率数据。存疑的输入 数据和约束条件 (“先验值”) 将导致参数估计出现偏差。在 这161个评估种群中, 会有部分种群的评估结果因输入数据的 质量问题被高估或低估,但目前的研究未发现系统性误差的 存在。

总体而言,本集刊中的文章共同组成了目前对东亚海 洋渔业状况最全面的评估。如果给每个评估种群一个 相同的权重,可以从这些评估结果中计算出每个区域当 前剩余生物量（或资源丰度）与未开发生物量（或丰 度）比值的平均值。中国大陆的平均百分比为 $25 \%$, 台湾 为 $16 \%$, 日本为 $30 \%$, 韩国为 $26 \%$ 。所有这些平均值都远低 于 $50 \%$, 即Schaefer $(1954,1957)$ 的经典资源评估模型要求生 成最大可持续产量的水平(Pauly and Froese, 2020)。虽然评估 结果显示东亚区域有尚未过度捕捞的种群, 但由于存在大量 剩余生物量与未开发生物量比值极低的种群, 因此东亚区域 该比值整体为 $25 \%$ 左右。

尽管东亚地区普遍存在过度捕捞现象早已被熟知 (Srinivasan et al., 2012; Li et al., 2017), 本集刊中的结果还提 供了新的信息,例如在捕捞压力降低情况下,用于计算过度捕 捞种群恢复时间所需要的参数的估计值(Demirel et al., 2020) 。这使得东亚的渔业学家可以计算科学的捕捞配额, 从而使 种群数量平均增加两倍, 增加的种群数量带来的收益将超过 减少捕捞压力导致的社会成本损失。

事实上, 在将 19 个食物网模型转换成粒度分布谱之后, Zhai and Pauly(b) 发现, 以中国大陆地区为代表的东亚沿海 海洋生态系统的功能正在逐渐被侵蚀, 渔业活动引起的大 
型鱼类物种的消失和剩余物种的小型化是造成这种现象的 主要原因。因此, 重建东亚种群不仅会在渔获量方面为渔

业带来经济利益, 而且还将重建功能健全、物种丰富的海 洋生态系统, 使渔业能够长期繁荣发展。

\section{REFERENCES}

Beverton, R. J. H., and Holt, S. J. (1957). On the dynamics of exploited fish populations. Ministry of Agriculture, Fisheries and Food. London: Fishery Investigations.

Demirel, N., Zengin, M., and Ulman, A. (2020). First large-scale Eastern Mediterranean and Black Sea stock assessment reveals a dramatic decline. Front. Mar. Sci. 7:103. doi: 10.3389/fmars.2020.00103

Froese, R., Demirel, N., Coro, G., Kleisner, K. M., and Winker, H. (2017). Estimating fisheries reference points from catch and resilience. Fish. Fish. 18, 506-526. doi: 10.1111/faf.12190

Froese, R., Winker, H., Coro, G., Demirel, N., Tsikliras, A. C., Dimarchopoulou, D., et al. (2018). A new approach for estimating stock status from length-frequency data. ICES J. Mar. Sci. 75, 2004-2015. doi: 10.1093/icesjms/fsy078

Li, J., Cao, K., Ding, F., Yang, W., Shen, G., and Li, Y. (2017). Changes in trophic-level structure of the main fish species caught by China and their relationship with fishing method. J. Fish. Sci. China 24, 109-119. doi: 10.3724/SP.J.1118.2017.16164

Pauly, D., and Froese, R. (2020). MSY needs no epitaph- but it was abused. ICES J. Mar. Sci. 78, 2204-2210. doi: 10.1093/icesjms/fsaa224

Schaefer, M. B. (1954). Some aspects of the dynamics of populations important to the management of the commercial marine fisheries. Inter Am. Trop. Tuna Comm. Bull. 1, $23-56$.

\section{AUTHOR CONTRIBUTIONS}

All authors listed have made a substantial, direct, and intellectual contribution to the work and approved it for publication.

Schaefer, M. B. (1957). A study of the dynamics of the fishery for yellowfin tuna in the eastern tropical Pacific Ocean. Inter Am. Trop. Tuna Comm. Bull. 2, 243-285.

Srinivasan, U. T., Watson, R., and Sumaila, U. R. (2012). Global fisheries losses at the exclusive economic zone level, 1950 to present. Mar. Policy 36, 544-549. doi: 10.1016/j.marpol.2011.10.001

Conflict of Interest: The authors declare that the research was conducted in the absence of any commercial or financial relationships that could be construed as a potential conflict of interest.

Publisher's Note: All claims expressed in this article are solely those of the authors and do not necessarily represent those of their affiliated organizations, or those of the publisher, the editors and the reviewers. Any product that may be evaluated in this article, or claim that may be made by its manufacturer, is not guaranteed or endorsed by the publisher.

Copyright (C) 2021 Pauly, Liang and Xian. This is an open-access article distributed under the terms of the Creative Commons Attribution License (CC BY). The use, distribution or reproduction in other forums is permitted, provided the original author(s) and the copyright owner(s) are credited and that the original publication in this journal is cited, in accordance with accepted academic practice. No use, distribution or reproduction is permitted which does not comply with these terms. 